\title{
LANDMARKS IN CHEMOTHERAPY
}

$\mathrm{T}$ HE forty-ninth Bedson Lecture was delivered by Prof. C. H. Browning at King's College, Newcastle-upon-Tyne, on March 11, the subject being "Landmarks in Chemotherapy". After defining chemotherapy and summarizing its position in 1900 , Prof. Browning traced the search for synthetic compounds with curative action in infections due to trypanosomes, spirochaetes, malarial parasites and bacteria. The first great advance was the discovery of trypan red, with which Ehrlich and Shiga (1904) cured a surely fatal infection due to certain trypanosomes in mice. It had the disadvantage of staining the body tissues and was of little practical value; but it led to Bayer-205, a colourless symmetrically substituted urea derivative. In the case of the latter the ratio of the maximum tolerated to the minimum curative dose is very large; any change, however slight, in its molecular structure causes a great diminution in its activity. It is the most effective drug for the cure of the African forms of human trypanosomiasis, provided that treatment is begun early. About the same time as the discovery of trypan red, the organic arsenical atoxyl was shown by Thomas at Liverpool to be active against trypanosomes in vivo. Although inactive in vitro, it becomes active in the test tube on reduction to the trivalent arsenic state. Therefore it seems that the drug is reduced in the body or even inside the trypanosome itself. The outcome of the investigation of arsenicals in Ehrlich's laboratory was salvarsan and its derivative neosalvarsan. The latter, especially from convenience in use, has come to be the most important drug in the treatment of syphilis.

For the treatment of malaria, in addition to quinine, Ehrlich and Guttmann in 1891 found methylene blue to be active in the quartan variety. In 1926 Roehl showed that a quinoline derivative, plasmoquine, was effective; it destroyed the sexual stage or crescent of the tropical variety, which is resistant to other drugs. Schulemann (1932) introduced atebrin, an acridine derivative which, like quinine, acts on the asexual stage. It is noteworthy that both these synthetic anti-malarial drugs possess the same sidechain--NH.CH $\left(\mathrm{CH}_{3}\right) \cdot\left(\mathrm{CH}_{2}\right)_{3} \cdot \mathrm{N}\left(\mathrm{C}_{2} \mathrm{H}_{5}\right)_{2}$-although they differ in the stage of the parasite which is attacked.

Scientific attempts to destroy bacteria in the tissues date from 1867, when Lister experimented with some success on the use of crude carbolic acid in the treatment of compound fractures. This was an example of the application of a 'surface' antiseptic which could be brought into intimate contact with an in. fected site.

Up to about 1914 it was believed that an antiseptic must be a general protoplasm poison, harmful alike to the bacteria and the infected host. But this idea was disproved by observations with the newer antiseptics, such as acriflavine and proflavine. An example is afforded by Blake's experiments on trout ova infected with $B$. salmonicida; although carbolic acid is almost equally toxic to both, a concentration of 1 : 2,000 acriflavine will kill the bacteria without appreciably damaging the ova. Experimental streptococcal infections have also been successfully treated with acriflavine as well as certain quino. line compounds of the Schiff's base type (anils), the method being to inject the organisms into the abdominal cavity and then after an interval to follow up with a solution of the drug. Such antiseptics are valuable for the treatment of local infections of wounds, especially as preventives.

As regards the treatment of general bacterial infections, in 1911 Morgenroth and Levy showed ethylhydrocupreine (optoquine) to be active against experimental pneumococcal infection in mice; this observation was of scientific interest only. The first compounds of practical value were the azo dyes derived from $p$-aminobenzene sulphonamide, used by Domagk, such as "prontosil soluble". Tréfouel et al. showed that it is the sulphonamide part of the molecule which is effective, and that the removal of the part linked by the azo grouping does not cause loss of activity. Sulphanilamide itself is fairly soluble and rapidly absorbed and excreted. Analogues, such as sulphapyridine, which have proved very useful clinically, are much less soluble and more slowly absorbed, so tending to maintain a more continuous action. Compounds of this class which are effective against streptococci in experimental infections, may fail with staphylococci.

While these drugs have revolutionized the treatment of meningococcal meningitis and gonococcal infections, and have profoundly modified the course of pneumonia, they appear to have little effect on some other infections, for example, tuberculosis.

\section{CONTROL OF TRANSPORT IN GREAT BRITAIN}

$\mathrm{W}$ HILE Lord Stamp and his fellow chairmen of the four great railway companies in Great Britain have made spirited replies to some of the criticism levelled at the railways in recent months, rail transport is only one aspect of a problem which has aroused widespread concern. The importance of transport in war has been well brought home to us in recent months by the measures designed to save shipping space, and the severity of the attacks on British and Allied shipping. It is only in a limited sense, however, that we have learnt that the power to transport may be the decisive factor, although its bearing on our blockade of Germany has been indicated by Dr. Hugh Dalton. That blockade can only be decisive if transport difficulties, intensified by bombing, reduce the enemy's supplies in his vast territories below what Dr. Dalton calls the 'distributional minimum'. We have yet to appreciate as a nation that the transport problem is a simple problem, and must be governed by national, not by commercial, considerations. The transport services in Great Britain must make their utmost contribu. tion to the war effort without regard to other considerations. 
This argument is the basis of Bulletin No. 5, "The Organisation of Transport for War", issued by the Vigilance-for-Victory Group (10 Hertford Street, London, W.1). It recognizes that some of the progressive slow-down of transport has been due to conditions directly imposed by the War, and that the transport services have done their best to overcome their formidable difficulties within the limits imposed by the nature of the transport service. While, however, it is of the utmost importance from the point of view of national defence that our internal lines of communication shall be organized and operated at the highest efficiency, there has been a falling off in efficiency which has substantially reduced the capacity of the transport services. Moreover, the system of internal communications must be considered as a whole. The greatest efforts of the most experienced officers with purely local functions can be frustrated by action in distant parts of the country without anyone being able to relate cause to effect. Failure to combine the highest professional experience with power and responsibility is the root cause of the situation which the recent appointments of two regional port directors are intended to correct.

The bulletin makes the point that transport difficulties are due to failure to co-ordinate transport supply with transport demand on a properly planned and organized basis, as was indeed indicated in Lord Stamp's address. Our present lines of communication are unnecessarily complicated because they have in the main been built up around, or in competition with, a method of railway operating, which however inevitable in the past, is no longer so, and is in itself complex. Statistics of the Ministry of Transport show the very low efficiency of railway operation and serious under-employment of equipment, and this is due to the methods of operating and the very low speed of movement. The delay in clearing ports and distributing supplies, even before mass air-attacks, was due to lack of ways, not of means. There appears to be no real shortage of equipment. The prime cause of the absence of organization is the persistent assessment of transport operations by their financial results and not by their service to national requirements.

The bulletin accordingly proposes that for the organization of our lines of communication for war purposes, the present advisory committee or consultative committees of the Minister of Transport should be abolished and replaced by a Transport Executive Council. Composed of professional transport officers of skill and experience, who would become full-time servants of the State, and func. tioning very much as the Board of Admiralty and the Army Council or the Air Council, this Council would handle the management and planning of transport services as a whole and decide the broad policy and major problems. The Minister of Transport would be president of the Council, which would directly control all forms of transport, each member of the Council being responsible for a group of departments. Regional organization would also be a matter for the Minister and the Transport Executive Council. While the precise form of regional organization would depend largely on the policy adopted to co-ordinate different forms of transport, it is probable that the simplest and most direct form of control would be through regional transport executive officers, who would exercise full authority over all forms of transport.

The War Transport Council just set up by the Minister of Transport would appear to be a step in the direction envisaged by the "Vigilance-for-Victory" Group.

\section{HUMUS FROM HABITATION WASTES}

\section{By Prof. R. H. Stoughton, UNIVERSITY OF READING}

HE disposal of the waste materials incident to
the existence of mankind has always been one
of the major problems of any large civilization.
Primitive man, leading a nomadic existence, left his
waste wherever he might be. As community living
developed, the midden became more and more a
necessary part of living conditions, and when towns
grew the disposal of waste products began to assume
the proportions of a real difficulty. The value of
animal and human excreta for the improvement of
the soil and for plant growth was discovered by
many races ; the possibility of returning decomposed
garbage to the soil similarly seems to have been
thought of at many times in history; the combina-
tion of the two appears, however, only to have been
practised in early times by the Chinese.
Western civilization developed the disposal of
refuse, first by dumping and later by incineration;
millions of tons of organic matter are, in one or
other of these ways, destroyed at the present time.
The wasteful disposal of excreta was later in coming.
Until the advent of water-borne sewerage, night-soil
still went back to the land, and a great deal of the
nitrogen taken from the soil by plants was returned
to it in this way. Then came modern systems of sewage disposal and all this 'went down the drain'. But water-borne sewerage, though bringing hygiene and health, brought also new problems of disposal, and thousands of tons of sludge containing only about five per cent or less of solid matter accumulate at every sewage works, and must be got rid of, either by dumping in the sea or by slow drying on extensive beds.

In the meantime our soil is crying out for organic matter. Without organic matter a soil is 'hungry' its moisture content, the essential key to plant growth, fluctuates wildly with the rainfall, and with its water its soluble mineral content varies. The agriculturist and horticulturist, recognizing the need for organic matter, have for centuries used dung and green manure as the source. Now the supply of animal manures is growing less every year; surely it is time something was done to stop the destruction of all the organic matter in habitation wastes and to convert them into a form suitable for restoring the organic content of the soil.

Lieut.-Colonel F. C. Temple in a recent paper ${ }^{1}$ discussed these difficulties and outlined the attempts which have been made to solve the problem of the economic utilization of these waste materials. The 